\title{
Plant Responses to Spring Grazing by Elk in Yellowstone National Park
}

\author{
EVElyn MERRILl ↔ NANCY Stanton \\ DEPARTMENT OF ZOOLOGY AND PhySIOLOGY $\downarrow$ UNIVERSITY OF WYOMING \\ LARAMIE
}

\begin{abstract}
Management of elk on the northern winter range of Yellowstone National Park has remained a controversial subject through most of this century (Singer 1989). Until 1968 elk were artificially controlled because it was believed that ranching outside the park excluded elk from winter ranges resulting in unnaturally high populations in the Park and uncontrolled elk numbers would result in overgrazing and ecosystem degradation. However, in 1968 elk reductions were terminated and by 1971 a hypothesis of natural regulation was formulated by Park biologists (Singer 1989). The natural regulation hypothesis asserts that the Yellowstone area used by elk is an ecologically complete habitat (all required components of the habitat are present) and that density dependant factors will limit population growth of elk without major range degradation.
\end{abstract}

Despite severe criticism of presumably deteriorated winter range, the natural regulation policy has been maintained based on the argument that animals have not greatly altered the range and that the primary purpose of natural areas such as Yellowstone is to "maintain ecological processes" (Houston 1982:1). Several studies in the 1970's using historical photographs supported the natural regulation hypothesis (Cayot et al. 1979, Barmore 1980). Houston (1982) in his book on the northern Yellowstone elk herd reported the natural regulation experiment to be largely successful through 1979 . However, major increases in elk as well as other ungulate populations in the Park since 1979 have prompted new concern over the success of the Park's management program (for example Alston Chases' book: Playing God in Yellowstone). We think that the Yellowstone winter range controversy can not be resolved until a better understanding of soil-plantherbivore system is achieved.

The first detailed information on grazing effects on plants of the northern winter range comes from recent comparisons of vegetation inside and outside exclosures established by the Park in the late 1950's (Singer 1989, Coughenour submitted). These studies found that dry weights of dead plant material were higher (6.2 times) in ungrazed exclosures than in grazed areas, and despite heavy grazing important forage species have persisted (as indicated by no difference in species composition and root biomass in grazed areas and in exclosures). However, aboveground production may be reduced by grazing particularly under drought conditions. Finally, nitrogen concentration of roots and aboveground foliage was higher when grazed. These studies concluded that winter grazing by ungulates had little negative effect on plants and that plants may even benefit by a shift in the flow of carbon from decomposers to ungulates with possibly an enhanced rate of nitrogen recycling back to the herbivores.

We hypothesize that aboveground herbivory by ungulates during spring green-up prior to migration 
alters below ground processes which, in turn, influences annual net primary production (NPP), nitrogen content of grazed plants, and morphological characteristics of plant regrowth as reported in the above studies. We suggest the following scenario results from spring grazing by elk prior to migration. Under the intense grazing in spring, grazed plants will initially show a decline in root biomass because photosynthesized assimilate will be allocated to regrowth (Detling et al. 1979). Phytophagous nematodes (that feed on roots) will decrease (Seastedt et al. 1988) but because senescing roots provide increased substrates for decomposers, microbial biomass and nitrogen mineralization should increase (Stanton et al. 1984). Dung (deposited during winter) as compared to litter amended soils will enhance these mineralization processes (Ruess and McNaughton 1987).

As regrowth occurs, carbon initially will be allocated to shoots (unless water is limiting, i.e. drought) and then to roots (Seastedt et al. 1988). Phytophagous nematodes will increase as new root growth provides nitrogen rich feeding sites (root hairs) but populations may not reach levels found under grazed plants for two reasons. First, because ungrazed plants experience lower levels of nitrogen mineralization than grazed plants, they will be nutrient stressed and produce proportionally greater numbers of root hairs (nutrient absorption organs) which serve as feeding sites for nematodes. Second, moisture stress usually brought on by summer drought limits phytophagous nematodes more than microbial feeders (Stanton et al. 1984).

The net result may be no detectable differences in above and below ground NPP during years of normal rain fall. However, during drought years, we would predict similar root production between grazed and ungrazed plants but reduced production of foliage of grazed plants. Nitrogen concentration may be higher in the foliage of grazed plants than ungrazed plants because of higher levels of nitrogen mineralization and nitrogen uptake per unit root biomass (Jarmillo and Detling 1988). This difference may extend into the winter period if tiller recruitment is extended such that plants are cured before nutrients are translocated to the roots (Anderson and Scherzinger 1975, Butler and Briske 1988). If grazed plants on the winter range are higher in nitrogen they may become preferred food items and sustain proportionally greater grazing pressure. However, if spring grazing induces changes in plant morphology (e.g. basal area, tiller density, and lengths: McNaughton 1979, Detling and Painter 1983), plants subsequently may be less intensively or frequently grazed because growth forms restrict bite size and intake rates of ungulates (Black and Kenny 1984, Illius and Gordon 1987). This may be an important trait temporarily allowing grasses to escape herbivory when high in nutrient content.

Because elk are migratory and graze the northern range primarily during winter, the effect of spring grazing on winter range vegetation largely has been ignored. We initiated a pilot study in 1990 to determine whether intense grazing of actively growing plants during this short but critical period plays an important role in the annual soil-plant-herbivore dynamics. Our study was designed to address 4 specific hypotheses:

1. Density of phytophagous nematodes will decrease and microbial feeders will increase on grazed plants as compared to ungrazed plants.

2. Root biomass of grazed and ungrazed plants will be similar.

3. Tiller density/unit of plant basal area will increase, and tiller length and weight will decrease as result of spring grazing.

4. Nitrogen concentration of soils, roots, and tillers will be higher in grazed than in ungrazed plants.

\section{Methods}

Our original design called for grazing manipulations with tame elk within enclosures in the upland steppe portion of the northern elk winter range during early spring. Because our tame elk were subject to a 3 month quarantine after entering the state of Wyoming, we were not able to use them in our grazing trails. Instead, we sampled inside and outside 6 small, exclosures $(1.5 \times 1.5 \mathrm{~m})$ and inside and outside one large exclosure $(100 \times 100 \mathrm{~m})$ located on Crystal Bench in Yellowstone National Park. Areas outside the exclosures were subject to natural levels of herbivory primarily by elk and bison. Plants within the large exclosure had not been grazed for 3 growing seasons prior to our sampling. Plants within the small exclosures were grazed during winter but not spring, i.e. small exclosures were established in April prior to green-up. 
Within the small enclosures, we randomly located 6 individuals of bluebunch wheatgrass (Agropyron spicatum) and Idaho fescue (Festuca idahoensis) using an $\mathrm{x}$-y coordinate system from a marked location. Our efforts focused on bluebunch wheatgrass (Agropyron spicatum) which is considered "grazing sensitive" and june grass (Koeleria cristata) which is not considered "grazing sensitive". Because of their caespitose and rhizomanous growth form, respectively, we counted the number of tillers of each idaho fescue "plant" and the number of tillers of bluebunch wheatgrass within a $18 \mathrm{~cm}^{2}$ area (area of our soil corer) circumscribing each bluebunch wheatgrass tiller chosen at random. Tiller height was measured to the top of the 3 tallest tillers. Two perpendicular basal diameters were measured on each Idaho fescue plant. These morphological characteristics were resampled at approximately 6 week intervals. During July, we also counted the number of flowering culms. Differences between characteristics of grazed and ungrazed plants were tested using pair-wise or comparisons.

Eight individual plants of each species were randomly selected and collected with a soil corer (diameter $4.8 \mathrm{~cm}$, depth $10 \mathrm{~cm}$ ) inside and outside the large exclosure. Previous studies by Dr. Stanton have indicated that this is an adequate sampling intensity to determine nematode densities. Cores were kept cool in a ice chest while transporting them to the laboratory where they were refrigerated until processing. Above ground biomass was clipped at $3 \mathrm{~cm}$ lengths starting at $2 \mathrm{~cm}$. Standing dead and green biomass was separated, dried at 50 degrees $C$ for at least 48 hours and weighed.

The soil cores were suspended in cold water and the soil gently washed from the roots. The suspension was sieved first to remove plant tissue (sieve \#18) and then to remove nematodes (\#325 mesh). Roots were hand-sorted while suspended in water and crowns cut from the roots. Roots and crowns were dried at 50 degrees $C$ for at least 48 hours and weighed. The suspension with nematodes was put on Baermann funnels for $48 \mathrm{hrs}$ (Christie and Perry 1951). Abundance and identification of nematodes to trophic category in each sample was determined by counting the number of individuals present in $21-\mathrm{ml}$ subsamples of a $30 \mathrm{ml}$ suspension as described by Smolik (1974). Randomly selected subsamples were re-extracted to measure extraction efficiency as follows: $92 \%$ for bacterial feeders, $91 \%$ for Dorylaimida (omnivores), $86 \%$ for Aphelenchus (fungal feeders), $93 \%$ for Tylenchidae (plant parasites) and $73 \%$ for Monohysteridae (unknown).

\section{$\downarrow \quad$ Data Analysis and Results}

Morphological measurements of individual plants were taken at three sampling dates: 11-12 May, 16-17 July, 8-9 September. Preliminary summaries indicate that there are significant differences in the heights of grazed and ungrazed plants of both species but not in tiller densities.

As expected, standing dead increases with time since grazing with significant differences between grazed and ungrazed plants evident by the end of the first season after rest from grazing. The amount of aboveground biomass that was green in September was greater in both grass species in grazed areas than nongrazed areas. Analysis of data on root biomass is not yet complete but the pattern of response appears different between species. Similarly, data analysis of changes in nematode composition and abundance between species and treatments is not complete. Preliminary results indicate that total densities under both species were bimodal with highest densities occurring in May and September. In these two months, densities of plant parasites on both grass species were lowest under ungrazed species while bacterial feeders exhibited no obvious trends. Additionally, nematode abundance under Idaho fescue is seasonally more variable than under bluebunch wheatgrass.

\section{Literature Cited}

Anderson, E.W., and R.J. Scherzinger. 1975. Improving quality of winter forage for elk by cattle grazing. J. Range Manage. 28:120-125.

Barmore, W.J. 1980. Population characteristics, distribution and habitat relationships of six ungulates in northern Yellowstone Park. Final Rep. Yellowstone Files.

Black, J.L., and P.A. Kenny. 1984. Factors affecting diet selection by sheep. II. Height and density of pasture. Aust. J. Agric. Res. 35:565-578.

Butler, J.L., and D.D. Briske. 1988. Population structure and tiller demography of the bunchgrass Schizachyrium scoparium in response to herbivory. Oikos 51:306-312.

Cayot, L.J., J. Prukop, and D.R. Smith. 1979. Zootic climax vegetation and natural regulation. Wildl. Soc. Bull. 7:162-169. 
Christie, J. R., and V. G. Perry. 1951. Removing nematodes from soil. Proc. Helminthol. Soc. Washington 18:106-108.

Detling, J.K., M.I. Dyer, and D.T. Winn. 1979. Net photosynthesis, root respiration and regrowth of Bouteloua gracilis following simulated grazing. Oecologia 41:127-134.

Detling, J.K., and E.L. Painter. 1983. Defoliation responses of western wheatgrass populations with diverse histories of prairie dog grazing. Oecologia 57:65-71.

Houston, D.B. 1982. The northern Yellowstone elk. Macmillan Publ. Co. New York. 473.

Illius, A.W., and I.J. Gordon. 1987. The allometry of food intake in grazing ruminants. J. Anim. Ecol. 56:989-999.

Jarmillo, V.J., and J.K. Detling. 1988. Grazing history, defoliation, and competition:effects on shortgrass production and nitrogen accumulation. Ecology 69:1599-1608.

McNaughton, S.J. 1979. Grazing as an optimization process: grass-ungulate relations in the Serengeti. Am. Nat. 113:691-703.

Ruess, R.W., and S. J. McNaughton. 1987. Grazing and the dynamics of nutrient and energy regulated microbial processes in the Serengeti grasslands. Oikos 49:101-110.

Seastedt T.R., R.A. Ramundo, and D.C. Hayes. 1988. Maximization of densities of soil animals by foliage herbivory: empirical evidence, graphical and conceptual models. Oikos 51:243-248.
Singer, F.J. 1987. Grazing effects of elk on Yellowstone's northem winter range. Yellowstone National Park Progress Report, Mammoth, WY.

Smolik, J. D. 1974. Nematode studies at the Cottonwood site. IBP. Grassland Biome. Tech. Rep. No. 251. Nat. Resour. Ecol. Lab. Colorad State Univ., Ft. Collins, Co.

Stanton, N.L. 1981. The effect of the pesticide carbofuran on soil organisms and root and shoot production in shortgrass prairie. J. Appl. Ecol. 18:417-431.

Stanton, N. L. 1983. The effect of clipping and phytophagous nematodes on net primary production of bluegrama, Bouteloua gracilis. Oikos 40:249-257.

Stanton, N.L., D. Morrison, and W. Laycock. 1984. The role of plant parasitic nematodes in blue grama die-off. J. Range Manage. 37:447-450.

Stroud, D.O.,R.H. Hart, M.J. Samuel, and J.D. Rodgers. 1985. Western wheatgrass response to simulated grazing. J. Range Manage. 38:103-108. 